\title{
SHEEP PRODUCTION AND HEALTH ON PURE-SPECIES PASTURES
}

J. W. McLean, G. G. THOMSON, C. E. IVERSEN, K. T. JAGUSCH, and B. M. LAWSON

The primary objective of this trial is to obtain basic data on the problem of so-called "ill-thrift" by relating soil conditions and seasonal changes in production and chemical composition of pure stands of various pasture species to the growth and health of the grazing. animals-in other words, a study of soil-pasture-animal relationships. In addition, the effects of certain trace elements and anthelmintics on lamb thrift have been studied. This paper summarises some of the results obtained during the second year of the trial.

In respect of traditional grassland practice in New Zealand, the grazing of pastures consisting of a single species may be regarded as somewhat artificial. As an experimental technique, however, provided pure stands can be established and maintained, the procedure has a number of advantages. It solves the difficult problem of establishing what the animal is eating from a mixed sward at any particular time; samples taken for chemical analysis can more reliably be related to what the animal is eating; seasonal variations in growth pattern and production of the various species under continuous grazing are emphasised; and subjective responses of the grazing animal are more readily observed.

\section{MATERIAL AND METHOD}

The experimental design in this trial comprised two replicates of two acre pasture plots of five species (lucerne, white clover, timothy, short-rotation ryegrass, and perennial ryegrass). The plots were established in early 1960 and have been maintained in a relatively pure state. Two shortcomings at present in this respect are some encroachment of the lucerne plots with white clover and the presence, from establishment, of some perennial ryegrass in the timothy plots. Throughout the grazing period, however. a high proportion--over 90 per cent-of the dry matter from the individual plots was produced by the species concerned.

Fertiliser treatment consists of $2 \mathrm{cwt}$ of superphosphate per acre on all plots and nitrogen in the form of urea-200-300 lb per acre-to the grass plots. 
Pasture samples are taken every two weeks for chemical analysis to establish levels of the macro- and micro-nutrients: $\mathrm{Ca}, \mathrm{P}, \mathrm{K}, \mathrm{Na}$, $\mathrm{Mg}, \mathrm{Mn}, \mathrm{Cl}, \mathrm{I}, \mathrm{Cu}, \mathrm{Co}, \mathrm{Mb}, \mathrm{Se}$, total $\mathrm{N}$, and NPN. At suitable intervals a check is also kept on pasture production by cutting and weighing the growth taking place under wire cages.

About the beginning of November 1961 the plots were stocked with early weaned-about 9-1 0 weeks-Corriedale (plus a few Corriedale-Border Leicester cross) wether lambs at the rate of 10 per acre. At this time all lambs were vaccinated against pulpy kidney disease, blackleg, and malignant oedema. Half of the lambs on each plot were treated with selenium $(5 \mathrm{mg}$ selenium as sodium selenate by mouth) at intervals of approximately eight weeks.

For the purposes of ruling out the effects of worm parasites, all lambs were treated with thiabendazole every three weeks, and the degree of control effected by the drug was checked at intervals by faecal egg counts and total worm counts in slaughtered animals. To measure differences in growth rate, the lambs were weighed at intervals of about two weeks. In early December, feed intake studies, using the chromium oxide technique, were carried out on 10 lambs from one set of replicates, 5 being in the selenium treated and 5 in the selenium untreated groups.

In January, March, and at the end of the trial in June, samples of lambs from each treatment group were slaughtered for stomach development studies and for fatty acid determinations on ruminal contents. Observations were made for any signs of ill health such as scouring, pizzle rot, and rickets.

\section{General Health}

With the exception of two which died of undetermined causes (one on clover in January and one on perennial ryegrass in February) all lambs remained healthy throughout the trial, although average growth rates in certain groups became stationary during part of January and February. There were certainly no signs of the typical "ill-thrift" with heavy losses that appeared in the previous year on the two types of ryegrass.

Some six or eight lambs only, out of 200, showed evidence of scouring and these were restricted almost entirely to the perennial rycgrass groups, and this despite the fact that the lucerne and clover at certain stages of lush growth would ordinarily have been regarded as highly conducive to scouring. In fact, a notable feature of the trial lambs was the virtual absence of scouring, particularly during the autumn flush period when the great majority of the lambs on other parts of the farm were scouring badly. 
Unless it was due to the effective control of parasites, no explanation can be given for the absence of scouring. We know from faecal egg-counts made in December and January and from total stomach and intestinal worm counts made on lambs slaughtered for rumen studies in January and March that thiabendazole, given every three weeks, to all extents and purposes gave complete control of parasites.

\section{Pasture Production}

A basic principle of this kind of trial is that any differences in the growth responses observed in the grazing stock should be referrible to differences in the quality of the pasture and that at no time should growth be limited by the quantity of feed available. In trying to adhere to this principle, owing to the unusual season, we were only partly successful. The complete absence of effective rain during the whole of October, November, and December accentuated the tendency of the ryegrass species to run to seed and dry off early in the season. Topping of both species had only a slight effect in maintaining the vegetative phase of growth. This, together with the normal warm, dry weather of January and February, led to severe depression of pasture production, particularly on the grass plots, to the extent that the stocking rate had to be reduced. Short-rotation ryegrass fared worst in this respect. It was completely destocked in January and one plotS.R. ryegrass IX-was surface sown for the autumn period.

Estimates of pasture production from the five species, together with the percentages of the total dry matter yielded by the respective pure species are set out in Table 1.

TABLE I-PASTURE PRODUCTION

(Total D. M. Ib per acre)

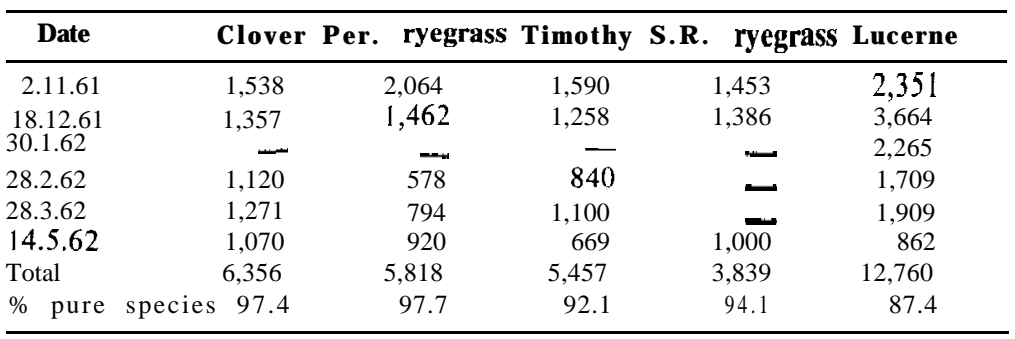

These data show that the total production in terms of dry matter per acre from the lucerne plots was twice that from clover, and that clover was followed by perennial ryegrass, timothy and shortrotation ryegrass, in that order. Total production was curtailed 
by a short spring and a very dry summer. The autumn, however, was exceptionally favourable. Lucerne shows to advantage in such a season, as also does clover, but to a less extent. The figures for November represent the amount of growth present at the start of the trial. By varying the intensity of early spring grazing, an attempt was made to have each plot at a similar stage of growth by early November.

\section{Growth Rates of Lambs}

The growth responses to the different pasture species arc presented in Figure | and Table 2.

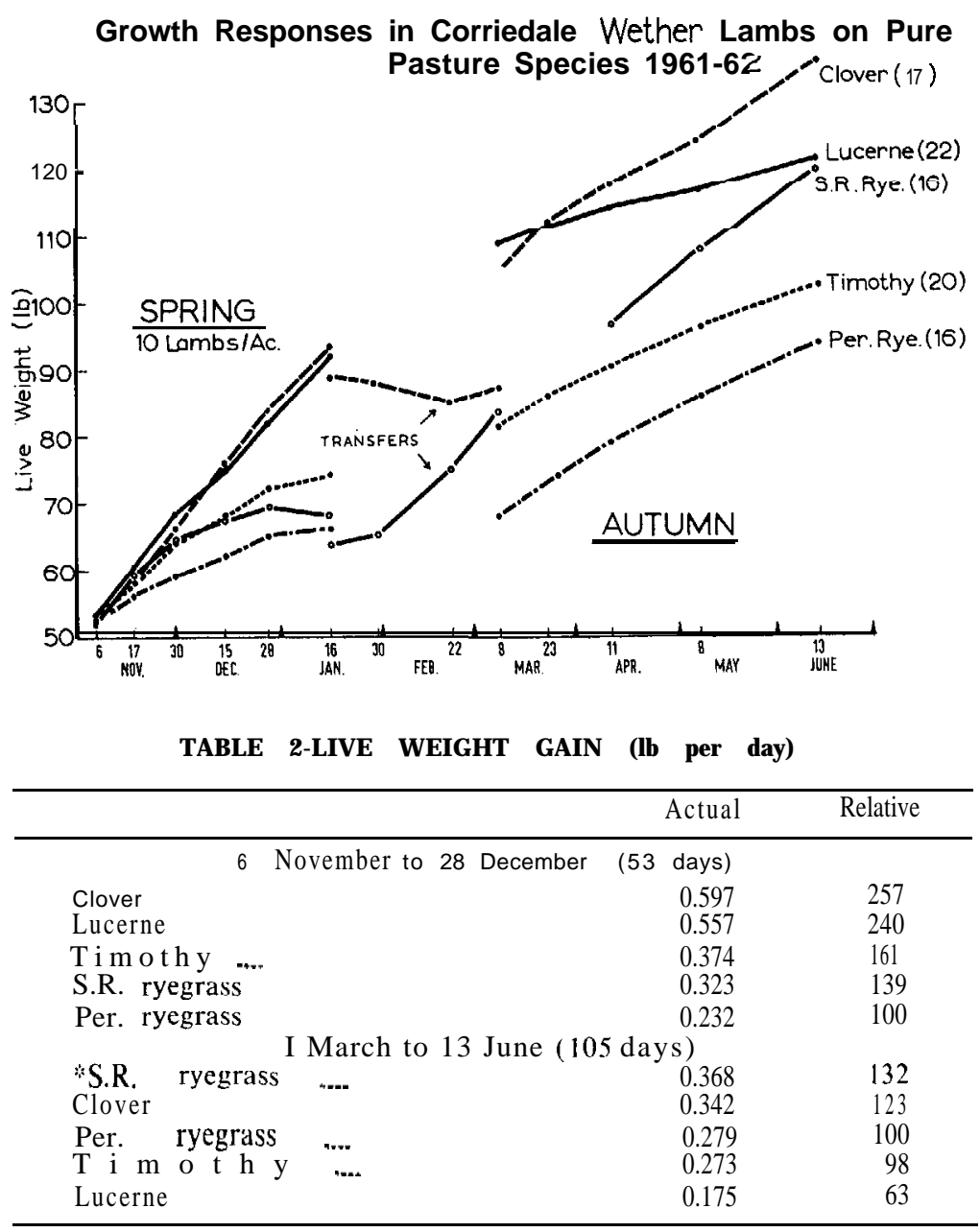

*1 I April to 13 June. 
Over the first 53 days up to 28 December, during which there was no scarcity of feed, the'growth rates show that the responses were highest on clover, with lucerne close behind, then a sharp fall to timothy, followed by short-rotation ryegrass, to the lowest on perennial ryegrass. The relative figures show that the growth rate on clover was $2 \frac{1}{2}$ times that on perennial rycgrass. It is of importance to note that this order and the relative differences arc substantially the same as those for the 1960-61 season, the preliminary year of the trial.

Over the autumn period (from March to June) the order according to growth rates changed slightly and the relative differences became less marked. The highest weight gains were made by lambs on short-rotation ryegrass over the last two months of the trial, the lambs on clover continued to make good gains, while the responses to lucerne over the latter period, when pasture growth fell away sharply, failed to be maintained at the previous high level. Except for short-rothtion ryegrass, which could be restocked only late in the season, the order of merit in respect of total weight gains remained the same: clover, lucerne, timothy, and perennial ryegrass.

A noteworthy feature of these data is the contrast between the total gains made on the legumes, on the one hand, and the grasses on the other. Special mention should be made of the lambs retained on clover throughout the whole of the trial period. These lambs averaged $141 \mathrm{lb}$ live weight-72 lb carcass weight-by mid June, a gain of $89 \mathrm{lb}$ in 219 days. To appreciate the significance of this, it may be noted that at this time of the year good Corriedale ewe hoggets average about $80 \mathrm{lb}$ live weight. The important factor in the achievement of high weights is the maintenance of a high rate of growth in the lambs during the dry summer period and through late April, May and June.

Clearly, the timing of the early stages of the trial places the grasses, particularly the ryegrasses, at a comparative disadvantage in that about the beginning of November, after producing heavily during late September and October, they enter their reproductive phase and, soon after this, production is further curtailed by the normal high temperatures and dry weather of January and February. In the later stages of the trial, from March through May, they compare more than favourably with the legumes. As pointed out earlier, these natural differences in growth pattern arc more apparent in pure stands.

\section{Selenium Responses}

The responses to selenium up to 28 December, in the various treatment groups are shown in Table 3. 
TABLE 3-SELENIUM RESPONSES

Nov. 6-Dec. 28, 1961, L. W. Gain (lb.) in 53 days

\begin{tabular}{lcccc}
\hline & & Control & Selenium & Difference \\
\hline Per. ryegrass & II & 9.6 & 13.1 & +3.5 \\
\multirow{2}{*}{ S. R. . ryegrass I V } & 12.3 & 14.2 & +1.9 \\
& & 15.5 & 19.1 & +3.6 \\
a over & IX & 16.2 & 17.4 & +1.2 \\
& I & 21.3 & 33.3 & +6.0 \\
\multirow{2}{*}{ Timothy } & VIII & 32.0 & 33.8 & +1.8 \\
& III & 21.0 & 20.4 & +0.6 \\
Lucerne & VI & 18.1 & 18.6 & +0.5 \\
& V & 21.6 & 28.6 & +1.0 \\
& X & 29.9 & 31.7 & +1.8 \\
\hline
\end{tabular}

Analysis of these data shows that there was a highly significant $(\mathrm{P}<0.01)$ over all response to selenium. Within plots, a significant $(\mathrm{P}<0.05)$ response occurred only on Clover $\mathrm{I}$, the responses on Per. ryegrass 11 and S.R. ryegrass IV reaching only the 10 per cent level of significance. Concerning differences in response to selenium between the average for species, the only two to differ significantly $(\mathrm{P}<0.05)$ are those for clover and timothy. No explanation for this difference is yet available. (The standard error for the mean of 10 lamb-weight gains in a plot was $1.57 \mathrm{lb}$.)

Selenium Responses and Food Intake

It will be recalled that early in December estimates were made of food intake, using the chromium oxide technique, on 10 lambs from one set of the replicates of the five treatment groups, five of which were treated with selenium and five not. The relationships between selenium treatment, food intake, and weight gain, up to the weighing immediately after the intake period, are shown in Table 4. The live weight gains are those of the lambs used in the intake studies.

TABLE 4-RELATIONSHIPS BETWEEN SELENIUM TREATMENT, WEIGHT GAIN, AND FOOD INTAKE

\begin{tabular}{|c|c|c|c|c|}
\hline & & & $\begin{array}{c}\text { Live weight } \\
\text { gain (lb) } \\
6.11 \text { to } 15.12\end{array}$ & $\begin{array}{c}\text { Estimated } \\
\text { Daily intake/day } \\
\text { D.O.M. } \\
\text { (lb) }\end{array}$ \\
\hline Per. ryegrass & VII & Selenium & 10.0 & 0.98 \\
\hline & & Control & 6.2 & 0.77 \\
\hline S.R. Ryegrass & IV & $\begin{array}{l}\text { Selenium } \\
\text { Control }\end{array}$ & $\begin{array}{l}15.8 \\
11.4\end{array}$ & $\begin{array}{l}0.98 \\
0.67\end{array}$ \\
\hline Clover & I & $\begin{array}{l}\text { Selenium } \\
\text { Control }\end{array}$ & $\begin{array}{l}24.6 \\
18.6\end{array}$ & $\begin{array}{l}2.85 \\
2.06\end{array}$ \\
\hline Timothy & VI & $\begin{array}{l}\text { Selenium } \\
\text { Control }\end{array}$ & $\begin{array}{l}14.2 \\
13.0\end{array}$ & $\begin{array}{l}1.21 \\
1.13\end{array}$ \\
\hline Lucerne & $\mathrm{V}$ & $\begin{array}{l}\text { Selenium } \\
\text { Control }\end{array}$ & $\begin{array}{l}19.2 \\
20.4\end{array}$ & $\begin{array}{l}1.75 \\
2.04\end{array}$ \\
\hline
\end{tabular}


It will be seen that the increased gains from selenium supplements on perennial and short-rotation ryegrass and clover are each associated with a higher food intake in the treated lambs. On certain types of feed it appears therefore that the action of selenium in stimulating growth rate is to increase the food intake. There may be a deficiency of nutritionally active selenium in some pasture species and this may lead to a depression in growth of the grazing animal, but as yet there is no real evidence for this. That the intake of certain pasture species is influenced by selenium while that of others is not, is a useful piece of information and an addition to our knowledge of the factors affecting intake.

While the intake measurement trial period constitutes only a small part of the period over which the live weight gains are calculated, there is a high correlation between the gains made and food intake expressed as digestible organic matter per day, and clear evidence of marked variation in the amounts of the different pasture species eaten by the grazing animals.

\section{Growth Rate and Stomach Development}

In recent years much has been learned about the development, structure, and function of the ruminant stomach, both from the point of view of the way in which each is modified in response to changes in the physical and chemical nature of the diet and of the effect of these modifications on the efficiency with which the food is utilised by the animals. An understanding of these processes is essential for a proper appreciation of the nutritional value of different kinds of feeds, be they pasture plants or any other foodstuff.

It is well known that the rumen microflora break down fibre and other carbohydrate constituents such as starch and soluble sugars into the so-called steam-volatile fatty acids (mainly acetic, propionic and butyric), which are quickly absorbed through the rumen wall. These products of microbial activity constitute the principal source of energy to the grazing ruminant. Fibrous foods such as mature pasture and hay give rise to a mixture of acids in which acetate predominates, while young lush pasture and grain lead to an increase in the proportions of propionate and butyrate. Mixtures high in acetate are in general less efficiently utilised than are those in which the ratio of acetate to the other two is narrower; that is, more is lost as heat during the energy transformations. Furthermore, the nature of the diet influences the rate of formation and the concentration of the total acids in the rumen.

It is also established that the proportions of the volatile fatty acids influence the development of the papillae of the ruminal epithelium. High acetate suppresses development and leads to 
regression in highly papillated stomaches, while high propionate and butyrate stimulate the rapid growth of these structures, thereby increasing markedly the total absorptive surface.

Finally, the physical nature of the diet influences the volume of the reticulo-rumen; in general, the coarser and more fibrous the food is, the greater is the stomach volume, an effect apparently brought about by a stretching of the walls and decreased papillation, since the total empty weight of the organ per unit of live weight tends to remain fairly constant.

At appropriate stages of the trial, lambs from the various groups were slaughtered for stomach structure and function studies in which the following measurements were made: live weight and carcass weight; the weight, full and empty, of each of the four compartments of the stomach; the volume of the reticulo-rumen at constant pressure; the degree of papillation over the whole rumen surface, assessed by eye and scored on a scale from 1 to 5 ; the number of papillae per unit area in three defined regions of the rumen; the length and width of the papillae in the sampled areas; the total volatile fatty acids per unit volume and the proportions of these in the form of acetic, propionic, and butyric acids.

A summary of these data is presented in Table 5.

TABLE 5-GROW'TH RATE AND STOMACH DEVELOPMENT

(November 6 to January 9-13)

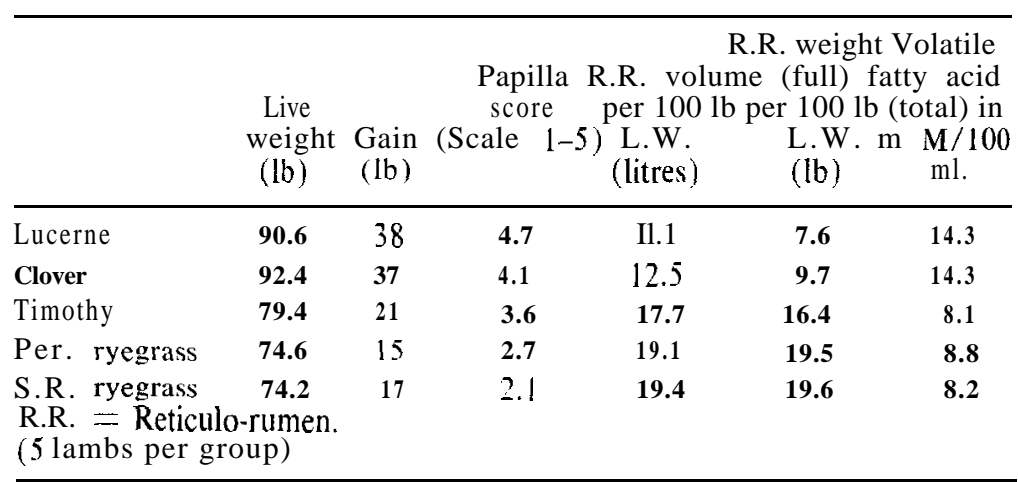

It will be seen that there is a very close direct correlation between live weight gain and papillary score. an equally close inverse correlation between live weight gain and the volume or full weight of the reticulo-rumen, and a clear relationship between live weight gain and the concentration of total volatile fatty acids. 
Furthermore, we have detailed data, which will be presented elsewhere, showing that the proportions of propionate and butyrate increase and that of acetate decreases with the increasing growth rate. An animal that is growing rapidly, therefore, has a small, highly papillated reticulo-rumen with a type of fermentation producing a high concentration of fatty acid mixture containing a high proportion of propionate and butyrate and low acetate, and its intake is high. The converse in all factors applies to the slowgrowing animal.

\section{Change of Feed and Stomach Development}

To study the extent and rate of change in structure and function of the rumen with changes in the nature of the food, one group of lambs was transferred from short-rotation ryegrass to lucerne, and another from clover to perennial ryegrass, that is, from a feed on which the growth rate was low to one on which it was high and vice versa. The transfers were made in mid January and the groups sampled for slaughter and stomach-development studies approximately eight weeks later. The respective control groups were also sampled. The results are presented in Table 6 .

tABLE 6-GROWTH RATE AND STOMACH DEVELOPMENT

Effect of Change of Feed

\begin{tabular}{|c|c|c|c|c|c|c|}
\hline & $\begin{array}{l}\text { Live } \\
\text { weight } \\
\text { (lb) }\end{array}$ & $\begin{array}{r}\text { Gain } \\
\text { (lb) }\end{array}$ & $\begin{array}{c}\text { Papilla } \\
\text { score } \\
(\mathrm{I}-5)\end{array}$ & $\begin{array}{c}\text { R.R. } \\
\text { volume } \\
\text { per } \\
100 \text { lb } \\
\text { L.W. } \\
\text { (litres) }\end{array}$ & $\begin{array}{c}\text { R.R. } \\
\text { weight } \\
\text { per } \\
100 \mathrm{lb} \\
\text { L.W. } \\
\text { (lb) }\end{array}$ & $\begin{array}{c}\text { Volatile } \\
\text { fatty } \\
\text { acids } \\
\text { (mM/100 } \\
\text { ml) }\end{array}$ \\
\hline$\overline{\text { S-R.R. } \quad \text { (control) }}$ & 17.3 & 3.0 & 1.3 & 19.4 & 16.0 & 10.5 \\
\hline $\begin{array}{l}\text { S.R.R. transferred to } \\
\text { lucerne }\end{array}$ & 87 & & & . & & \\
\hline Lucerne (control) & $\begin{array}{r}01.2 \\
103.6\end{array}$ & 22.0 & $\begin{array}{l}4.2 \\
4.0\end{array}$ & $\begin{array}{l}13.1 \\
11.6\end{array}$ & $\begin{array}{l}9.5 \\
7.3\end{array}$ & $\begin{array}{l}18.0 \\
16.5\end{array}$ \\
\hline Clover (control) & 105.7 & 22.0 & 4.3 & 10.5 & 6.5 & 15.0 \\
\hline $\begin{array}{l}\text { Clover transferred to } \\
\text { perennial }\end{array}$ & 946 & 40 & 26 & 149 & 134 & 104 \\
\hline Perennial (control) & 71.6 & $\begin{array}{l}4.0 \\
8.0\end{array}$ & $\begin{array}{l}.0 \\
2.3\end{array}$ & 16.3 & 14.3 & $\begin{array}{l}10.4 \\
10.7\end{array}$ \\
\hline
\end{tabular}

These data demonstrate very clearly that with the transfer from the relatively fibrous short-rotation ryegrass to the lush lucerne, increased rate of growth is associated with a dramatic change in both structure and function of the rumen towards the pattern characteristic of the lucerne-grazed animals; and the converse is equally well demonstrated in the animals transferred in the opposite direction-in this instance from clover to perennial ryegrass. 
It is of interest to note that these remarkable and significant responses in structure and function of the ruminant stomach to the different kinds of pasture on the one hand, and to the sudden changes from one type of pasture to another on the other hand, take place in a period of not more than eight weeks. Tt is clear that lesser, yet recognisable, changes must take place in a much shorter time.

Special notice should be taken of the fact that with the change from a fibrous to a succulent feed the full weight and the volume at constant pressure of the reticulo-rumen both fall almost to those characteristic of the lambs grazed continuously on succulent feed.

Let us now look at these findings in relation to the value of the various pure-species pastures for the purposes of production of meat, with the object of determining the attributes that make one type better or worse than another.

Provided each contains the required amount and assortment of essential food constituents in the form of vitamins, minerals, fats, and nitrogenous compounds and is free of potentially toxic substances-and, as yet, we are by no means sure of this-the capacity of the animal to produce will be set by the following factors :

(1) The total amount of energy in the form of pasture that it will eat in a given time per unit of live weight; this is usually referred to as total intake, expressed as dry matter.

(2) The proportion of this which can be digested and absorbed, and therefore is not lost in the faeces, that is, the digestibility. This is primarily a function of the amount of "fibre".

(3) The rate at which the food can be handled by the digestive tract-the rate of passage; this appears to be primarily a function of the activity of the ruminal microflora which, in turn, depends upon the composition of the food, especially in relation to the proportion of soluble and more readily available carbohydrate and protein.

(4) The rate of absorption of the volatile fatty acids (V.F.A.) from the reticulo-rumen; this is facilitated by a high concentration of fatty acids, a low $\mathrm{pH}$, and an extensive absorptive area provided by heavy papillation.

(5) The relative proportions of acetic, propionic, and butyric acids formed during the breakdown of carbohydrate by the ruminal microflora; the efficiency of conversion increases progressively from acetic to butyric acid. 
(6) The energy cost of grazing; where the amount of pasture per unit area is high the energy cost of grazing is low and vice versa. In this trial, in general, where the amount per unit area was high the quality of the pasture was also high and vice versa. It is likely that this factor is of little significance under the conditions of this trial.

Many of these factors are interdependent. For example, a high intake depends on high digestibility and a fast rate of passage; the latter is associated with a small stomach (low fill) and a type of fermentation producing a high concentration of total acids of which up to 40 per cent or more are propionate and butyrate; this leads to heavy papillation, a low $\mathrm{pH}$, rapid absorption, and efficient conversion of the energy derived from carbohydrate (and probably also from protein).

This represents the state of affairs in the lambs grazing white clover and lucerne over the greater part of the trial. The composition of these species, in terms especially of carbohydrate other than cellulose and hemicellulose, was such as to lead to efficient utilisation and high intake, and consequently high live-weight gains. As pointed out by McDonald (1962), the possibility that the high protein content may have had some effect in maintaining the high intake must not be overlooked.

In the grasses, on the other hand, particularly the ryegrasses during the period from November to February, the levels of monoand oligo-saccharides decline and the cell-wall components gradually accumulate as the plants mature. These changes lead to a change in the type of fermentation in the rumen, with a fall in digestibility and rate of passage, an increase in stomach volume, and a marked reduction in intake. Furthermore, the proportion of acetate rises to 70 per cent or more, the papillae atrophy, and the efficiency of conversion of the energy from carbohydrate decreases. Protein digestion may also suffer. The end result is a decline in the rate of live-weight gain.

It is true that the ryegrasses show to better advantage in the autumn (when short-rotation ryegrass in particular proves to be a first-rate feed) and probably would do so in early spring (a period not as yet covered in these trials), but their inability to produce a continuous supply of high quality feed and surmount the vicissitudes imposed by normal variations in soil temperature and moisture must be regarded as a serious shortcoming in these species.

Timothy falls in a somewhat intermediate position between the legumes and the ryegrasses. It stands up well to continuous grazing and shows less seasonal variation than the ryegrasses in the quality 
of feed produced. Outside all objective standards of comparison, lambs grazing on this species look fit and act in some indefinable way as though life were worth living.

These results, in general, confirm and amplify to some extent those of Johns and his associates ( 1962) in Palmerston North.

\section{Acknowledgements}

Acknowledgement is willingly made of the generous financial assistance towards the conduct of this project from the Department of Agriculture. Wellington, and of the assistance in statistical work from $\mathrm{Mr}$ Graham Wright of the Crop Research Division, D.S.I.R., Lincoln. Thanks are due to Merek Sharp and Dohme (N.Z.) Ltd. for the thiabendazole used in this trial.

\section{References}

A. T. Johns (1962): "Some Aspects of Rumen Metabolism Influencing Intake and Production in Sheep." Proceedings of the N.Z. Society of Animal Production.

lan W. McDonald (1962) : "Nitrogen Metabolism in the Rumen." Proceedings of N.Z. Society of Animal Production.

\section{DISCUSSION}

Q. How do you arrange the rate of stocking for these trials because some of the effects could be put down as pure intake effects as a result of differential growth?

A. This is one of the major difficulties in such a trial, and as I mentioned, we were only partly successful as a consequence of the very dry season we had about twelve months ago. I think the data presented over most of the trial period give the responses of the lambs lo qualitative effect mainly. Certainly in the early spring and in the late autumn all the responses were associated basically with differences in the quality of the feed and at no stage during those periods was there a restriction of growth through an absence of feed. I think this could be qualified in this fashion; there obviously are changes in the composition of pasture over the season and I think we must recognise that this takes place, and take cognisance of it. Even although there is feed there, if it changes in composition with respect to other species, which do not change so markedly in composition, then we have a limitation of thal particular grass over that particular period.

Q. (1. L. Elliott) : We haven't done any work at Rukuhia with timothy and lucerne but, in the trials that Dr Davies has done, there was a big difference between browntop and ryegrass, where it was found that the levels of selenium were much higher in the browntop than in the ryegrass. You say chemical analyses are being done and I am looking forward keenly to see how these things pan out.

A. Yes that is most important. There was no reference made to the selenium content of the pastures, but merely to the fact that we got responses to selenium dosed to the animal on some of the pasture species, and not on others, and it will be interesting indeed to find out whether there are differences in gross selenium content of those species. 
Q. (J. Tripp): Would it be possible to offset the effect of dosing with selenium by the use of certain other pasture species such as timothy in the sward, where it is suggested that the level of selenium may be high?

A. No. I don't think we could yet say that that is possible, because we haven't chemical analyses to show that there are differences in selenium content. In the light of other information it would be rather unexpected to find that there was no response on lucerne. Much of the early work on white muscle disease was done in Oregon where it was shown that lucerne from certain regions produced the disease while that from other regions didn't. It was also shown that there were no differences in the gross selenium content, so at the moment I don't think we could say that you could grow timothy and avoid the need for dosing selenium.

Q. (L. Corkill): I am intrigued by the work that Prof. McLean has outlined and particularly with the relationship between the single species and their effects on animals. We must realise that the trial has only been carried out over a short time, the observations being restricted to November-January, and that over this period grasses would make very little growth. At the same period legumes would be doing relatively well. Will you indicate if the results would have been the same if some other period of the year such as autumn had been chosen?

A. No. The result would be different as was presented by the data. I agree with you that we did have a problem in trying to prevent perennial and $\mathrm{H} 1$ from running to seed. As a consequence of this phase of growth, one would expect a higher fibre content, lower digestibility, and this is reflected in the results. The results also showed that during the autumn some of the highest rates of growth were experienced on short rotation ryegrass, which was young and actively growing. Over the period from April till mid-June the highest rates of growth were experienced on those grasses and that was followed by clover which certainly continues to grow most of the year. There were differences too in lucerne which tended to change in its composition in some fashion or other but not in its total production. From the appearance of the pasture there was never an absence of food on the lucerne plots, particularly one of the lucerne plots, yet there were differences in the rate of growth. The rate of growth fell off in late autumn on the lucerne. The problem that we have is to start the trial much earlier in the season on the basis of its present design of using lambs wholly. One would like to start the trial mid-September for preference but as yet we haven't learned a way of doing that unless we lamb our lambs on to it. But there certainly are differences as you have pointed out. On the other hand I can't help feeling impressed by the fact that when you do sow grasses in pure species it emphasises the differences in growth pattern which is not so obvious when you have them growing together.

Q. (N. Cullen): Did you have trouble in maintaining the species pure, particularly the white clover. Secondly, what was the grazing height at the time the plots were grazed? Did the stock show any obvious grazi ng preferences'?

A. In the control of the plots before they were stocked we tried to graze them so that they would all be approximately equal at the commencement of the trial, which meant that we hoped that they would have about 6-8 in. growth on each plot. Secondly we have had a little trouble, in maintaining the plots pure, but on all of the pasture cut for 
estimates of production, purity was examined and all of them gave above 92 per cent pure on a DM basis so that there has been no real problem there except that we have used some of the hormonal weedicides as a means of controlling grasses within the clover; we haven't yet had to use anything to control the clovers in the grasses. The difference in behaviour has not been marked. In the late autumn there was a tendency for the $\mathrm{H} 1$ to have been grazed, leaving patches, but this has not been a marked or obvious feature of the plots.

Comment (Mr Iversen): Firstly with regard to purity we have maintained a very high degree of purity. We used $2 \mathrm{lb}$ of Dalapon on the lucerne and on the clover in the previous June, so I trust that that did not upset the experiment. The purity of the grasses was maintained largely by the nitrogen that was added as urea. We didn't get as much of that on as I would have liked. Referring to Dr Corkill's comment; this is a peculiar sort of experiment and I regard it as one of the most valuable experiments I have seen because we can learn something from it. But do not imagine this is the production you would get from a 2 acre paddock, of perennial ryegrass, or from $\mathrm{HL}$. This is the relative production you got during this particular and peculiar season. I quite agree that the legumes and summer grasses are flattered, while the winter growing species, like $\mathrm{H} 1$ and to a lesser extent perennial, are not flattered by doing all the measurements over that summer period. Also, the very dry summer, an attack of Argentine stem weevil, and a bit of porina etc., did affect the HI in the summer. 